\title{
УЧАСТЬ АРСЕНА РІЧИНСЬКОГО В РОБОТІ «ПРОСВІТИ» НА ЗАХІДНІЙ ВОЛИНІ (1924-1934 РР.)
}

У статті проаналізовано участь відомого громадсько-політичного, культурно-просвітнього діяча Арсена Річинського у функиіонуванні «Просвіти». Досліджено його місие і роль у прачі товариства на Західній Волині. У міжввєнний період доволі поширеною формою украӥнського культурно-просвітницького руху була «Просвіта», головним завданням якого були поширення освіти серед украӥнців, ознайомлення їх із надбанням рідної культури, захист культурних, правових і економічних інтересів украйнського населення. Актуальною була проблема самоосвіти. Для цьього товариство відкривало бібліотеки, книгарні, створювало читальні, організовувало масові культурно-освітні заходи, поширювало періодику, займалося видавничою діяльністю, брало безпосередню участь в організачії українських шкіл.

На Волині значного визнання набула «Просвіта» у Володимирі-Волинському, до якої належав А. Річинський. Ï̈ засновано восени 1919 р. Станіславом Полянським. А. Річинський вступив у «Просвіту» в 1924 р., обіймав посаду референта культурно-освітньої праці, а з 1927 р. став головою товариства. Він сприяв розвитку місиевого просвітянського хору, долучився до формування бібліотек, діяльності читалень, організацї свят, відзначення видатних історичних подій. А. Річинський був активним учасником різних просвітянських форумів, на яких вирішувались організачійні питання та напрями діяльності «Просвіти». Зокрема, він був учасником III з '̈зду «Волинських Просвіт» та ІІ Всеукраӥнського освітнього конгресу у Львові.

Участь А. Річинського в роботі «Просвіти» зумовлена тим, щчо він, будучи свідомим украӥнським патріотом, намагався через культурно-просвітницьку працю організовувати бібліотеки, читальні, масові культурно-освітні заходи, поширювати періодику, засновувати школи тощзо. На початку 1920-х рр. иее був єдиний легальний метод протистояння насильницькій полонізації українства в Західній Волині.

Ключові слова: Арсен Річинський, «Просвіта», бібліотеки-читальні, товариство, Західна Волинь, міжвоєнний nepiod.

\section{Kravchuk Olena. Participation of Arsen Richynsky in the work "Prosvita" in Western Volhynia (1924-1934)}

The article analyzes the participation of the well-known socio-political, cultural and educational figure Arsen Richynsky in the functioning of "Prosvita". Its place and role in the work of the society in Western Volhynia have been studied. In the interwar period, a fairly common form of Ukrainian cultural and educational movement was "Prosvita", the main task of which was to spread education among Ukrainians, acquaint them with the heritage of native culture, protect cultural, legal and economic interests of the Ukrainian population. The problem of self-education was urgent. To do this, the society opened libraries, bookstores, created reading rooms, organized mass cultural and educational events, distributed periodicals, engaged in publishing, participated in the organization of Ukrainian schools.

In Volhynia, Prosvita in Volodymyr-Volynskyi, to which A. Richynsky belonged, gained considerable recognition. It was founded in the fall of 1919 by Stanislav Polyansky. A. Richynsky joined "Prosvita" in 1924, held the position of cultural and educational the head, and in 1927 became chairman of the society. He contributed to the development of the local educational choir, joined the formation of libraries, reading rooms, organization of holidays, celebrations of outstanding historical events. A. Richynsky was an active participant in various educational forums, which addressed organizational issues and activities of "Prosvita". In particular, he was a participant in the III Congress of "Volyn Prosvita" and the II All-Ukrainian Educational Congress in Lviv.

A. Richynsky's participation in the work of "Prosvita" is due to the fact that he, being a conscious Ukrainian patriot, tried through cultural and educational work, to organize libraries, reading rooms, mass cultural and educational events, distribute periodicals, establish schools and more. In the early 1920s, this was the only legal method of resisting the forcible Polonization of Ukrainians in Western Volhynia.

Key words: Arsen Richynsky, "Prosvita”, reading libraries, society, Western Volhynia, interwar period.

У міжвоєнний період доволі поширеною формою українського культурно-просвітницького руху була «Просвіта», головним завданням якого були поширення освіти серед українців, ознайомлення їх iз надбанням рідної культури, захист культурних, правових і економічних інтересів українського населення. Актуальною була проблема самоосвіти. Для цього товариство відкривало бібліотеки, книгарні, створювало читальні, організовувало масові культурно-освітні заходи, поширювало періодику, займалося видавничою діяльністю, брало безпосередню участь в організації українських шкіл. 
На Волині значного визнання набула «Просвіта» у Володимирі-Волинському, до якої належав А. Річинський. Ї̈̈ засновано восени 1919 р. Станіславом Полянським. О. Цинкаловський у книзі «Княжий город Володимир» писав, що «... відкриття цієї важної культурно-освітньої організації прийняли володимирчани з великим захопленням. Слідом за Володимиром починають відкриватись читальні «Просвіти» в повіті, по різних селах та містечках. У 1929 році у Володимирівському повіті діяло 74 просвітніх читалень» $[1$, с. 92-93].

Варто зауважити, що в Західній Волині становлення просвітницького руху відбувалося в інших умовах, ніж у Східній Галичині, де «Просвіта» виникла у 1868 р. і набула значного досвіду в організації культурно-просвітницької та інших форм роботи. У східногалицькому середовищі в міжвоєнний період інституція відігравала надзвичайно важливу роль, оскільки ії поступ сприяв формуванню національної свідомості та патріотизму українців. Натомість у Західній Волині, яка перебувала у складі Російської імперії, просвітницький рух зародився значно пізніше. На початку 1920-х рр. «Просвіта» перебувала на організаційній стадії й діяла 3 певною обережністю [2, с. 27].

У міжвоєнний період «Просвіта» Східної Галичини намагалася поширити свою діяльність на всю територію Польщі, про що свідчив варіант нового статуту, в якому акцентувалося на тому, що «тереном діяльності $\epsilon$ ціла держава Польська». Влада з огляду на власні інтереси забороняла поширювати діяльність товариства не лише на територію усієї Польщі, але й на Волинь, оскільки там «Просвіта» не мала централізованої структури, діяла на підставі окремих статутів. На землях Волині, Холмщини, Підляшшя й Полісся засновувалися самостійні товариства «Просвіта» з окремими статутами. Відповідні осередки діяли в Кременці, Дубно, Рівному, Луцьку, Горохові, Володимирі, Ковелі, Бресті, Холмі. Кожен із них мав право засновувати бібліотеки-читальні лише в межах свого повіту. До 1926 р. таких бібліотек-читалень діяло 600 [3, с. 30-31].

Із приходом до влади у 1923 р. «ендеків» змінюється курс урядової політики щодо економічного розвитку західноукраїнських земель. Основою прийнятої економічної концепції було гальмування розвитку «східних кресів» і перетворення їх на аграрно-сировинний придаток до більш розвинутих промислових районів Польщі. У руслі такої політики польський уряд уподовж першої половини 20-х рр. $\mathrm{XX}$ ст. різко обмежив, а в багатьох випадках і зовсім припинив кредитування промислових підприємств у Західній Україні, насамперед українських кооперативних установ. Щодо Західної Волині, то її промисловість фактично до кінця 20-х рр. ХX ст. не отримувала державних інвестицій.

Кооперація посідала важливе місце в господарському житті українців у міжвоєнний період. Нестача державних коштів, високі кредитні ставки банків посилили роль і значення кооперативних спілок у повоєнній відбудові господарства. «Просвіта» здійснювало активну діяльність у сфері кооперації, саме вона започаткувала і поширювала кооперативний рух, організовувала кооперативні крамниці, позичкові каси та зерносховища, де селяни мали змогу придбати за доступними цінами необхідні товари, позичити гроші, зерно тощо. Основними видами кооперації, які впроваджувала в життя «Просвіта», були ощадно-позичкові каси та кооперативні банки. Це пояснюється тим, що населення Західної Волині в основному займалося сільським господарством і лише 7\% були зайняті у промисловості. Тому після проведення реорганізації аграрного устрою найбільшого розмаху тут набуває ідея створення кредитної кооперації [4, с. 107].

А. Річинський брав активну участь у кооперативному русі. Він був членом української економічної організації, фінансового центру української кооперації «Українбанк» [5, с. 2], який з 5 жовтня 1924 р. розпочав діяльність у Луцьку, згодом утворено філію у Володимирі-Волинську. Цей банк надавав короткотермінові і середньотермінові позики жителям навколишніх сіл. Документальною основою для надання позики був вексель. Основним завданням кредитної кооперації було надання фінансової допомоги сільським товаровиробникам шляхом кредитування. На позики кредитних установ сільські кооперативи купували сільськогосподарську техніку, сортове насіння, міндобрива, будували молочарні, олійні та інші кооперативні споруди, зводили «народні доми». Кооперативна система кредитного обслуговування сільського господарства значно зменшувала залежність кооперації, відповідно, українців від польської державної банківської системи. У цьому плані діяльність кредитних спілок мала важливе позитивне значення [4, с. 108]. Згодом у Володимирському повіті діяло до 40 кооператив, які до 1934 р. належали до Ревізійного Союзу Українських Кооперативів, а від 1934 р. перейшли до новоутвореного Волинського Ревізійного Союзу [1, с. 96].

У 1924 р. змінено статут «Просвіти», в якому усунено параграф про економічну діяльність, формально товариство економічною сферою не займалося, відтоді праця товариства скеровувалася лише на культурно-освітне життя. За ініціативи «Просвіти» в Луцьку відбулися два просвітні з'їзди філій товариства, на яких схвалено резолюцію про утворення централі «Волинської «Просвіти», обговорено 
iї статут. Ухвалено заснувати «Волинську «Просвіту», яка мала б діяти на території усієї Волині, але польська влада на це не погодилася [6, с. 2369-2371]. Воєводське управління відмовилося реєструвати прийнятий з'їздом статут «Волинської «Просвіти». Ухвалу воєводства 3 травня 1925 р. підтвердило Міністерство внутрішніх справ Польщі [2, с. 29].

Весною 1922 р. А. Річинський із дружиною переїхали із с. Тростянець на постійне місце проживання у Володимир-Волинський. Важливу роль для здійснення переїзду мав фах лікаря, позаяк А. Річинського, згідно із розпорядженням Волинського воєводства від 24 квітня 1922 р., переведено у Володимир-Волинський дільничним лікарем [7, с. 12]. Він активно долучився до діяльності «Просвіти». Зберігся список членів «Просвіти» у Володимирі-Волинському, складений її керівником С. Полянським у 1924 р. Товариство на той час нараховувало 65 осіб, з них 50 чоловіків і 15 жінок. Найактивнішими були С. Полянський та Х. Озерів, вони належали до ради «Просвіти». Серед активних учасників також названі Ніна та Арсен Річинські [8, арк. 5]. 3 часом А. Річинський обіймав посаду референта культурноосвітньої праці, а з 1927 р. став головою товариства [9, с. 18].

«Просвіта» у Володимирі-Волинському не мала постійного фінансування та значного грошового забезпечення. Фінансові звіти філій товариства і касові книги засвідчують, що кошти надходили від пожертвувань громадян. Наприклад, у звіті філії товариства у с. Тишкевичі зазначено, що у 1925 р. каса нараховувала 38,5 злотих, з яких використано на потреби 31,56 злотих. Кошти витрачали на найнеобхідніше: столи, крісла, книги, газети [10, арк. 6]. Повітова «Просвіта» у Володимирі-Волинському працювала в основному на громадських засадах. Фактично діяльність відбувалася без матеріального заохочення. Члени товариства вносили свої заощадження, щоб закупити чи видати літературу. Спогад про становлення у Володимирі-Волинську «Просвіта» і організацію бібліотеки залишила Ніна, дружина А. Річинського: «Створити «Просвіту» у Володимирі національно свідома інтелігенція вирішила на початку 20-х років. Песимісти, а серед них священник Микола Широцький сказав, що з цього нічого не буде. Я і мені подібні вирішили зібрати молодь міста, зокрема інтелігенцію. На окраїні міста жив старий Краєвський в досить просторій хаті, займаючи одну половину. Ось для культурних цілей і вирішили ми використати другу частину його оселі... Прийшов і доктор Станіслав Полянський. В хаті зробили танці. В перерві я кажу: «Може, наступного разу кожний принесе зі своєї бібліотеки по одній-дві книжки та започаткуємо бібліотеку. Наступного разу всі поприносили різні книги. I зараз пам'ятаю їх назви: «Мотря» Б. Лепкого, твори Шевченка, Лесі Українки, інші. Почали населенню ставити вистави. Я сама грала в «Назара Стодолі» Т. Шевченка. Розповсюджували лотереї, «танці по запрошенню». Навіть польська влада до нас мала симпатію. Ми намагалися поширювати все наше, українське» [11, с. 33].

А. Річинському доводилося співпрацювати з багатьма відомими українськими громадськими діячами. Це, наприклад, Михайло Тележинський, відомий композитор, диригент, публіцист, політичний діяч, який у міжвоєнний період проживав у Володимирі-Волинському. «Просвіту» у ВолодимиріВолинському відвідував Олександр Кошиця. На Волині він відбирав здібних учасників хорової капели. Демократичними поглядами в товаристві відзначався Дем'ян Герштанський, священник Василівської церкви. До автокефального церковного руху він ставився з обережністю, але був членом «Просвіти». Активно працював у товаристві майбутній відомий історик, археолог О. Цинкаловський, який чимало зробив для відкриття невідомих сторінок історії Волині [12, с. 223]. До діяльності «Просвіти» у Володимирі-Волинському причетні Н. Річинська, М. Савич, І. Зубович, М. Вітовський, С. Комаревич, М. Панасевич, Ю. Бунда, О. Березовська, В. Березовський, В. Крайц та інші [8, арк. 5].

А. Річинський, обіймаючи посаду референта культурно-освітньої праці у «Просвіті», активізував іiі різнобічну культурно-просвітницьку працю. Організовував курси, влаштовував академії, вистави, концерти, вечорниці. Окрім читалень, повітова «Просвіта» у Володимирі-Волинському утримувала дві просвітянські школи в селах Біличі й Осмиловичі та інші приватні українські школи, які діяли в селах Володимирівського повіту (одна з найвідоміших у с. Новосілки), приватні курси для дітей [1, с. 94; 13, с. 10].

Завдання «Просвіти» полягало в тому, щоб організувати сільські бібліотеки-читальні, які були б корисними не лише для тих, хто вже навчився читати, але й для неписьменних. Як свідчить звіт громадсько-політичного і культурно-просвітнього діяча М. Галущинського та історика I. Крип'якевича 3 поїздки у серпні 1923 р. Волинню й Холмщиною, бібліотека товариства у Володимирі-Волинську нараховувала 400 томів. На освітній нараді, яка проходила у Львові 27 жовтня 1926 р., М. Галущинський у виступі зазначав, що, незважаючи на слабкі організаційні форми просвітницького руху на Волині, «... бібліотечна справа поставлена там високо, як ніде у Галичині...» [3, с. 31].

За сприянням «Просвіти» організовувалися читальні у повіті, кількість яких у 1929 р. нараховувала 74. Бібліотека товариства у Володимирі-Волинському та їі читалень становила понад 15 тис. книг [1, с. 94]. Безпосередню участь у формуванні фондів бібліотеки брали С. Полянський та О. Цинкаловський, із 
часом долучився А. Річинський, про що свідчать їхні підписи під списками книг, якими користувалися хати-читальні. Каталоги читалень Володимирського повіту засвідчують, що найбільше місцеві мешканці читали твори М. Грушевського, І. Огієнка, Б. Лепкого і В. Винниченка [11, с. 42]. За свідченням I. Власовського. бібліотеки «Просвіти» отримували такі українські газети, як «Українська громада», «Наше життя», «Українська нива», «Наше слово» та інші. До осені 1927 р. у бібліотеках товариства нараховувалося 29 назв газет [14, с. 7-8].

Основні питання щодо організації та напрямів діяльності «Просвіти» в Західній Волині вирішувалися на просвітянських форумах або з'їздах представників повітових товариств. Важливе значення мав III з'їзд «Просвіти» Волині, скликаний 26 вересня 1926 р. у Рівному. Це було зібрання представників українських культурно-освітніх організацій Волині за участі представників від Холмщини і Підляшшя, а також зацікавлених осіб зі Східної Галичини та Полісся. На нього прибуло близько 270 делегатів з усієї Волині. Від «Просвіти» у Володимирі-Волинському делеговано А. Річинського, який увійшов до складу президії з'їду [15, арк. 1].

Президія з'їзду, в тому числі й А. Річинський, затвердила порядок денний, який складався з таких пунктів: питання приватного шкільництва у зв'язку з поширенням статуту «Рідної школи» на усі українські землі; справа фізичного виховання (поширення і легалізація спортивних і пластових гуртків, шляхи й методи їх організації; об'єднання просвітянської праці; святкування 10-ліття «Просвіти» тощо). Окрім того, ухвалено вважати рішення з'їзду обов’язковими для усіх осередків «Просвіти» на Волині [16, с. 3].

На з'їзді планувалося провести восени 1927 р. у Рівному IV з'їзд повітових «Просвіт» Волині, але через заборону польської влади його не скликано. На Волині й надалі існували окремі повітові «Просвіти», які не мали, як це було у Східній Галичині, об’єднуючого центру. Правда, у 1927 р. воєводське управління розробило типовий «Примірний статут Волинської Просвіти». Проте діячі українського культурно-освітнього руху відмовилися його приймати [2, с. 30].

При «Просвіті» функціонували мистецькі колективи - музичні, театральні, хореографічні. Зокрема, А. Річинський, обіймаючи посаду референта культурно-освітньої праці, сприяв розвитку місцевого просвітянського хору. Серед усіх хорів Волині саме хоровий колектив «Просвіти» у Володимирі-Волинському здобув найбільшої слави. Хором керував диригент, композитор і публіцист М. Тележинський. Концертна діяльність хору розпочалася з 1922 р. і сприяла зростанню професійної майстерності учасників колективу. Він став своєрідним явищем у виконавстві. Діяльність колективу не обмежувалася лише концертними виступами, за сприянням А. Річинського хор брав участь у богослужіннях у Володимирському кафедральному соборі, в якому вперше на Волині виконав літургію українською мовою $[17$, c. $24-25]$.

При читальнях повітової «Просвіти» створювалися аматорські гуртки, які набули широкого поширення і користувалися популярністю в навколишніх селах. У такому театральному гуртку брала участь i дружина А. Річинського. Вона грала у виставі «Назар Стодоля» Т. Шевченка [11, с. 33]. Також ставилися вистави «Наймичка», «За батька», «Пещена дитина», «Наталка Полтавка» та інші, на постановку яких польська влада 31928 р. перестала надавати дозволи [18, с. 4].

«Просвіта» започаткувала надзвичайно яскраву традицію вшанування пам’яті національних героїв, відзначення видатних історичних подій. Наприклад, дні пам’яті І. Франка - 28 травня, М. Драгоманова 15 червня та I. Котляревського - 10 листопада, свято хрещення України - 14 липня, свято книги - 1 жовтня, свято «Просвіти» - 8 грудня. Хоча програми їх проведення попередньо погоджувалися у повітових староствах, проте у них завжди панував український дух, зазвичай усі вони закінчувалися виконанням національного гімну «Ще не вмерла Україна» [19, с. 49].

А. Річинський, будучи головою «Просвіти», організовував для членів товариства у ВолодимиріВолинську відчити відомих громадських діячів. Зокрема, йому вдалося отримати дозвіл від місцевої польської влади на проведення зустрічі 23-24 червня 1928 р. із Дмитром Донцовим. 23 червня відбулись відчити Д. Данцова для інтелігенції Володимирського повіту, на котрих він проголосив доповідь на тему «Європа чи Росія». У неділю 24 червня було організовано другі відчити для селян і міщан, тому матеріал доповіді мав більш популярний характер: прозвучала тема «Перспективи комуністичної ідеї». Річинський зазначив: «В цей спосіб наша Рада («Просвіти» - від автора) хоче використати Вас, Пане Редактор, так, щоб і для ширших кол дати популярний поважний матеріал, i для стислого гуртка інтелігенції уможливити авдіцію відповідну» [20, s. 525]. Під час перебування у Володимирі-Волинському Д. Донцов зупинявся у Річинських, що засвідчує їхні тісні стосунки [20, s. 526].

У серпні 1929 р. від Д. Донцова до А. Річинського знову надійшла пропозиція влаштувати відчити у Володимирі-Волинську. У той час А. Річинський перебував у Карпатах у пластових таборах, тому цю 
пропозицію передав раді товариства «Просвіта» та «Союзу Українок», які спільно мали намір запросити Д. Донцова до Володимира-Волинського [20, s. 527].

А. Річинський, як активний громадсько-політичний і культурно-просвітній діяч, голова «Просвіти» у Володимирі-Волинському, був учасником II Всеукраїнського освітнього конгресу, який проходив 22-24 вересня 1929 р. у Львові, завершального етапу святкування 60-річного ювілею «Просвіта» $[21$, c. 236$]$.

А. Річинський брав активну участь у роботі секції позашкільного виховання [22, арк. 2-4]. Він виголосив доповідь на тему «Просвіта» й український церковний рух на північно-західних землях», в якій висвітлив участь товариства в національному церковному русі на Волині та озвучив спільні проблеми духовенства та просвітян Волині. Проведення згадуваного конгресу «Просвітою» із представників Східної Галичини, Західної Волині й інших регіонів України було свідченням активності і визнаного авторитету просвітнього руху й сприяло формуванню національної самосвідомості українства.

У кінці 1920-х рр. політична ситуація у Західній Волині була складною й неоднозначною. Польська влада проводила антиукраїнську політику з метою якнайшвидшого інтегрування регіону до складу Речі Посполитої, чим зумовила ліквідацію «Просвіти». Після прибуття на Волинь воєводи Г. Юзевського посилилися репресії щодо «Просвіти». Вважаючи товариство політичною експозитурою українського націоналізму Східної Галичини, у 1928 р. ліквідували 318 просвітніх осередків. У цьому ж році «Просвіта» припинила функціонування в Рівненському, Ковельському й Дубнівському повітах, у 1929 р. у Володимирському. До середини 1930-х рр. ліквідовано більшість осередків «Просвіт» на Волині, упродовж 1928-1936 pр. - 630 осередків товариства, в яких нараховувалося 17700 членів [2, с. 32-33].

Складна ситуація, в якій опинилася «Просвіта» у Володимирі-Волинську, змусила А. Річинського спільно з радою товариства 21 листопада 1929 р. скликати загальні збори, попередньо проінформувавши староство, однак дозволу на зібрання вони не отримали. 23 листопада поточного року польська влада офіційно повідомила «Просвіту», що ії діяльність у Володимирі-Волинському і повіті призупинено [17, с. 4].

А. Річинський та активні члени «Просвіти» намагалися отримати дозвіл від польської адміністрації на відновлення діяльності товариства. Однак А. Річинський спільно із С. Полянським, О. Цинкаловським та С. Назаруком після оголошеної заборони діяльності «Просвіти» не складали своїх повноважень і не припиняли просвітянської праці. У Володимирському повіті й надалі продовжували функціонувати 13 читалень. Коли ж їхні намагання на відновлення діяльність товариства були марними, то лише через чотири роки після офіційної заборони «Просвіти» у Володимирі-Волинську ними створено ліквідаційну комісію [23, арк. 10]. 30 жовтня 1934 р. керівництво «Просвіти» у Володимирі-Волинському склало свої повноваження, передавши частину майна «Союзові українок» [23, арк. 90].

Головний виділ «Просвіти» у Львові 15 жовтня 1934 р., передаючи майно товариства у Володимирі-Волинському, повідомляв про наявну фінансову заборгованість повітового товариства. У 1935 р. остаточно списане усе майно, яке, згідно з одностайною постановою останніх ліквідаційних зборів, передали «Просвіті» у Львові [1, с. 96].

Таким чином, участь А. Річинського в роботі «Просвіти» зумовлена тим, що він, будучи свідомим українським патріотом, намагався через культурно-просвітницьку працю організовувати бібліотеки, читальні, масові культурно-освітні заходи, поширювати періодику, засновувати школи тощо. На початку 1920-х рр. це був єдиний легальний метод протистояння насильницькій полонізації українства в Західній Волині. Обмежуючи просвітню працю осередків товариства, влада прагнула не допустити утворення об'єднуючого ядра в Західній Волині, на кшталт Головного виділу «Просвіти» у Львові, тому осередки товариства діяли як окремі повітові структури і філії в сільських місцевостях. Тим не менше наслідки праці «Просвіти» були важливими, позаяк вони сприяли поступу українства, утвердженню національної самосвідомості, патріотизму, збереженню рідної мови, самобутньої культури.

Література:

1. Цинкаловський О. Княжий город Володимир : попул.-наук. нарис. Львів : Накладом фонду «Учітеся, брати мої», 1935. $111 \mathrm{c}$.

2. Кучерепа М. Становлення та діяльність просвітянських організацій на Волині (1918-1939 рр.). Науковий вісник Східносвропейського наиіонального університету імені Лесі Українки. Історичні науки. 2016. № 3. С. 27-35.

3. Зуляк I. Взаємини «Просвіти» Східної Галичини з Волинню у міжвоєнний період. Наукові записки Тернопільського наиіонального педагогічного університету імені Володимира Гнатюка. Сер.: Історія / голов. ред. І. Зуляк ; редкол. : М. Алексієвець, Л. Алексієвець, М. Бармак [та ін.]. 2013. Вип. 1: у 2 ч. Ч. 1. С. 30-32.

4. Вісина Т. Зародження і розвиток кредитної кооперації на Волині (друга половина XIX ст. - 1939 р.). Збірник навчально-методичних матеріалів і наукових статей історичного факультету. Луцьк : Ред.-вид. відділ ВДУ, 2001. № 6. C. 107-110. 
5. Річинський А. Автобіографія. 1954 р.: [рукопис]. ВКМ: 3 стор., мова рос.; КДФ-15143, КВ-67620. Додаток 1.

6. Кравців Б. «Просвіта». Енциклопедія украӥнознавства / гол. ред. Володимир Кубійович. Репр. відтворення вид. 1955-1984 р. Львів : НТШ, 1996. Т. 6. С. 2365-2376.

7. Колодний А.М. Життя і творчість Арсена Річинського - самовіддане служіння Богу й Україні. Річинський А. Проблеми украӥнської релігійної свідомості. Тернопіль : Укрмедкнига, 2002. С. 11-50.

8. Протоколи зборів та списки членів товариства «Просвіти» у Володимирі 1924-1932 рр. Держархів Волинської обл. Ф. 390. Оп. 1. Спр. 11.6 арк.

9. Візітів Ю. Пластовий сеніор А. Річинський: «До щастя, слави і свободи». Арсен Річинський: видатний украйнський громадський діяч і науковець-релігієзнавець. Науковий збірник. Київ-Кременець, 2007. С. 17-23.

10. Касова книга філії товариства в селі Тишкевича. Держархів Волинської обл. Ф. 390. Оп. 1. Спр. 23.21 арк.

11. Пісоцький А. Інтелігенція Волині: погляд крізь призму часу. Луцьк : Волин. обл. друк., 2009. 173 с.

12. Пісоцький А. Арсен Річинський в становленні національної свідомості Волині в 20-30-х роках XX століття. Минуле і сучасне Волині та Полісся: Ковель і ковельчани в історї Украӥни та Волині: матеріали ХХІХ Всеукр. наук, icm.-краєз. конф. : збірник наук. пр. Луцьк : Надстир'я, 2008. С. 222-224.

13. Пісоцький А., ВойтюкН. Просвіта Володимирщини в 20-30-х роках. Слово Просвіти. 2013. Ч.26.4-10липня. С. 10 -11.

14. Власовський, І. Луцька «Просвіта» (10 років просвітянської праці 1918-1928 рр.). Львів, 1928. 70 с.

15. Інформація воєводської коменди державної поліції про діяльність «Просвіти» на Волині. Держархів Волинської обл. Ф. 46. Оп. 9. Спр. 1026. 8 арк.

16. Ломимо кордон. З’їд представників волинських «Просвіт» у Рівному. Діло. 1926. 30 вересня. С. 2-3.

17. Шиманський П. Музична культура Волині I половини XX ст. : монографія. Луцьк : РВВ «Вежа» Волин. держ. ун-ту ім. Лесі Українки, 2005. 175 с.

18. Просвіта у Володимирі загрожена (Допис з Волині). Діло. 1929. 28 листопада. С. 4.

19. Рожко В. Роль товариства «Просвіта» в організації і проведенні Шевченківських Академій у 20-30-х роках XX ст. на Волині. «Просвіта» на Волині: минуле і сучасне : Збірник наук. ст., док. і матеріалів / Волин. держ. ун-т ім. Лесі Українки; За ред.. В.К. Барана. Луцьк, 2001. С. 48-56.

20. Archiwum Dmytra Dontsova. Bibliteka Narodowa. Warszawa. MF № 83985. $596 \mathrm{~s}$.

21. Зуляк I. Освітній конгрес «Просвіти» - завершальний етап святкування 60-літнього ювілею товариства у міжвоєнний період. Література та культура Полісся / Відп. ред. і упоряд. Г. В. Самійленко. Ніжин : Вид-во НДУ ім. М. Гоголя, 2005. Вип. 29. С. 236-245.

22. Матеріали про проведення пленарних засідань усіх учасників II го Всеукраїнського освітнього конгресу у Львові 22-го і 24 вересня 1929 р. (програма, реєстри учасників, протоколи, резолюції та інші документи зв'язані 3 цим). ЦДІАЛ України. Ф. 348. Оп. 1. Спр. 130. 43 арк.

23. Статут товариства, протоколи ліквідаційних зборів, список майна та книг. Держархів Волинської обл. Ф. 390. Оп. 1. Спр. 80. 181 арк. 